\title{
Giving Children a Voice in Court?
}

\author{
Age Boundaries for Involvement of Children in Civil Proceedings and the Relevance of \\ Neuropsychological Insights
}

Mariëlle Bruning \& Jiska Peper*

\begin{abstract}
In the last decade neuropsychological insights have gained influence with regard to age boundaries in legal procedures, however, in Dutch civil law no such influence can be distinguished. Recently, voices have been raised to improve children's legal position in civil law: to reflect upon the minimum age limit of twelve years for children to be invited to be heard in court and the need for children to have a stronger procedural position.

In this article, first the current legal position of children in Dutch law and practice will be analysed. Second, development of psychological constructs relevant for family law will be discussed in relation to underlying brain developmental processes and contextual effects. These constructs encompass cognitive capacity, autonomy, stress responsiveness and (peer) pressure.

From the first part it becomes clear that in Dutch family law, there is a tortuous jungle of age limits, exceptions and limitations regarding children's procedural rights. Until recently, the Dutch government has been reluctant to improve the child's procedural position in family law. Over the last two years, however, there has been an inclination towards further reflecting on improvements to the child's procedural rights, which, from a children's rights perspective, is an important step forward. Relevant neuropsychological insights support improvements for a better realisation of the child's right to be heard, such as hearing children younger than twelve years of age in civil court proceedings.
\end{abstract}

Keywords: age boundaries, right to be heard, child's autonomy, civil proceedings, neuropsychology

\section{Introduction}

The last decade has witnessed the increased influence of neuropsychological insights on age boundaries in legal proceedings. In the Netherlands, recent law amendments with regard to the introduction of 'adolescent criminal law' clearly reflect the influence of neuropsychological findings with regard to adolescent brain development. For instance, based on the well-replicated

Mariëlle Bruning is Professor of Child Law at Leiden Law Faculty, Leiden University. Jiska Peper is Assistant professor in the Developmental and Educational Psychology unit of the Institute of Psychology at Leiden University. findings that - on average - the brain continues to mature up until twenty-five years of age, ${ }^{1}$ young adults (of eighteen to twenty-three years of age) can be sentenced under criminal law as children based on the personality of the suspect or the circumstances of the criminal offence. ${ }^{2}$ Nevertheless, in Dutch civil law, no such influence can be distinguished. ${ }^{3}$ In Dutch civil law, different age limits with regard to the participation of children in procedures are used, and many different exceptions with various age limits can be discerned. Children lack legal capacity - locus standi - and are no independent party to the proceedings. Parents or guardians are responsible to represent them in civil court proceedings, and when a conflict of interests between the child and the legal representative(s) can be established, the court can appoint a guardian ad litem ('bijzondere curator') to represent the child.

Children who experience civil law proceedings are mostly involved in family law or child protection proceedings. In such proceedings, tensions often exist between the interests of parents and child. Recently, voices have been raised to improve children's legal position in civil law: to reflect upon the age limit of twelve years for children to be invited to be heard in court and the need for children to have a stronger procedural position. ${ }^{4}$ This article focuses on children, their current procedural possibilities in civil law and possible findings to improve their current position as legally incompetent parties in civil proceedings concerning children (family law or child protection proceedings). We aim to answer the question: to what extent are current age limits for children in Dutch family law in conformity with neuro-

1. K.L. Mills, A.L. Goddings, M.M. Herting, R. Meuwese, S.J. Blakemore, E.A. Crone, R.E. Dahl, B. Güroğlu, A. Raznahan, E.R. Sowell \& C.K. Tamnes, 'Structural Brain Development Between Childhood and Adulthood: Convergence Across Four Longitudinal Samples', 141 Neuroimage 273 (2016).

2. $\quad$ Art. 77c Dutch Criminal Code.

3. Empirical studies into the neuropsychological development of the adolescent brain can also be useful for reflecting upon the transition from youth to adulthood at the age of eighteen and legal problems when transferring from a child protection system for children to a system that can hardly respond to young adults who are not willing to accept professional support but who are incapable of living independently without having serious problems, such as behavioural or psychiatric problems or substance abuse. Still, in this article we will focus on the position of children and not on young adults who have experienced mandatory care and support during their childhood.

4. Government Committee on Reassessment of Parenthood, Child and Parents in the 21st Century (2016). 
psychological insights? First, the current legal position of children in Dutch law and practice will be analysed (section 2). After a brief introduction of the child's right to be heard, the child's right to be heard in family law proceedings, recommendations for improvement of the child's legal position and political unwillingness to act upon recommendations for Dutch civil law will be discussed. Furthermore, current age limits for children in Dutch civil law will be compared with the legal position of children in other Dutch law contexts. Second, development of psychological constructs relevant for family law will be discussed in relation to underlying brain developmental processes and contextual effects in children (section 3). These constructs encompass cognitive capacity, autonomy, stress responsiveness and (peer) pressure. What is known from recent literature on the development of these neuropsychological processes in children and - based on these insights - is there a need for change of their legal position in family law? In the final part (section 4) of this article, we will address the question what lessons can be learnt from neuropsychological insights for Dutch family law.

\section{The Current Legal Position of Children in Dutch Law and Practice}

\subsection{The Child's Right to Be Heard}

Children have the right to be heard according to Article 12 of the Convention on the Rights of the Child (hereinafter CRC), and this includes the right for all children who are capable of forming their own views to express those views freely in any judicial proceedings, such as civil proceedings, 'either directly, or through a representative or an appropriate body' (Art. 12 section 2 CRC). ${ }^{5}$ The right to be heard, as enshrined in Article 12 CRC, includes three components: (1) the right to infor-

5. For some critical voices about the still rather vague contents of Art. 12 CRC and Committee on the Rights of the Child, General Comment No. 12. The Right of the Child to be Heard, UN Doc CRC/C/GC/12 (2009), see e.g. A. Daly, Children, Autonomy and the Courts. Beyond the Right to be Heard (2018), A. Daly, 'No Weight for "Due Weight"? A Children's Autonomy Principle in Best Interest Proceedings', 1 International Journal of Children's Rights 61 (2018); A. Parkes, Children and International Human Rights Law. The Right of the Child to be Heard (2013), at 120; C.R. Mol, 'Children's Representation in Family Law Proceedings. A Comparative Evaluation in Light of Article 12 of the United Nations Convention on the Rights of the Child', 1 International Journal of Children's Rights 66 (2019). From a European perspective, Art. 6 ECHR includes the right of access to court. The right of access to court is not absolute but may be subject to limitations, for example, for children, but these must not restrict or reduce the access in such a way or to such an extent that the very essence of the right is impaired (ECHHR 21 February 1075, ECLI:CE:ECHR:1975:0221JUD000445170, Golder v. UK). The Court has ruled that procedures should be adapted to the developmental stage of the youth suspect; see A. Daly and S. Rap 'Children's Participation in Youth Justice and Civil Court Proceedings', in U. Kilkelly and T. Liefaard (eds.), International Human Rights of Children (2018) 299-319. However, the ECtHR has not addressed age limits with regard to child participation. mation about being heard, (2) the right to be heard and (3) the right to be taken seriously by way of their views being given due weight in accordance with the age and maturity of the child. In addition to the fact that the right to be heard is an obligation that arises from the CRC, a large number of studies show that participation for children has a number of positive effects. ${ }^{6}$

The Committee on the Rights of the Child dedicated their General Comment Number 12 to the child's right to be heard and emphasised that

Article 12 imposes no age limit on the right of the child to express her or his views, and discourages States parties from introducing age limits either in law or in practice which would restrict the child's right to be heard. ${ }^{7}$

The Committee on the Rights of the Child acknowledges that some jurisdictions prefer to state an age at which the child is regarded as capable of expressing his or her own views - age limits are often used in domestic procedural law. Yet, the Committee assures that, according to the CRC, children's capability to express their own views should be determined on a case-by-case basis and this requires an individual assessment of each individual child. ${ }^{8}$

However, many countries have included age limits that impede the child's right to be heard in legal proceedings. The Fundamental Rights Agency of the European Union looked at statutory provisions in ten member states of the European Union regarding the child's right to be heard in civil cases and found, in 2015, that age limitations are often incorporated in domestic law with regard to the child's right to be heard. ${ }^{9}$ Furthermore, differences can be found in the scope of the right to be heard. In some countries, the right to be heard is limited to a single interview by a judge, but in other countries, children have the possibility to present evidence, to intervene in a case or to receive court rulings. ${ }^{10}$ Age limits can hinder the child's right to be heard in legal proceedings in two ways: absolute age limits that are reflected in law can restrict children's participation in legal proceedings, but also age limits in law can lead to an interpretation of law that obstructs the child from being

6. S. Rap, D. Verkroost, \& M.R. Bruning, 'Children's Participation in Dutch Youth Care Practice: An Exploratory Study into the Opportunities for Child Participation in Youth Care from Professionals' Perspective', 25 Child Care in Practice 37 (2019).

7. Committee on the Rights of the Child, above n. 5, at para. 21.

8. Ibid., at paras. 52 and 102; with regard to health care, the Committee welcomes the introduction of a fixed age at which the right to consent transfers to the child, but strongly recommends that where a younger child can demonstrate capacity to express an informed view on his or her treatment, this view is given due weight.

9. M.R. Bruning and K.A.M. van der Zon, 'Can You Hear Me? Children's Right to be Heard in Child Protection Proceedings in the Netherlands', paper presented at World Congress on Family Law and Children's Rights, June 2017, Dublin.

10. European Union Agency for Fundamental Rights, Child-Friendly Justice - Perspectives and Experiences of Professionals on Children's Participation in Civil and Criminal Proceedings in 10 EU Member States (2015), at 309; Bruning and Van der Zon, above n. 9. 
heard in legal proceedings in practice. In Dutch civil law and practice, age limits are common. In the next paragraph, the use of age limits in Dutch civil law and their implementation in practice will be further discussed.

\subsection{Dutch Family Law and Children's Legal Position}

Under Dutch family law, a child is a person under the age of eighteen. ${ }^{11}$ Children lack legal capacity, although in the past few decades many exceptions to this rule have been added to the Dutch Civil Code. ${ }^{12}$ Only their parents or other legal guardians can initiate civil proceedings and act as an independent party. ${ }^{13}$ Parents who bear parental responsibility are responsible for the child's legal representation in civil matters. ${ }^{14}$ In case of a conflict of interests between the child and his or her legal representative (parent or legal guardian), the court can appoint a guardian ad litem $^{15}$ ('bijzondere curator') who can represent the child in civil proceedings and instigate such proceedings. Guardians ad litem in the Netherlands are usually trained as (family or children's) lawyers or as educationalists (behavioural experts). Furthermore, in some family law matters, Dutch law provides children with the possibility to approach the court informally and ask for a specific decision. This informal access to the court is available in matters related to custody after divorce and contact between a child and a parent. ${ }^{16}$

Despite their legal incapacity, children are interested parties in all family proceedings, ${ }^{17}$ including proceedings concerning child protection measures such as a family supervision order. Moreover, they have the right to be heard in court proceedings if they are twelve years or older and are not regarded legally incompetent to express their will. ${ }^{18}$ Children younger than twelve years of age can be heard on their request if the court decides that the child is competent. In this part of our review we will further elaborate on children's procedural position in family law proceedings and the use of related age limits.

\subsection{Age Limits in Dutch Civil Law}

Although the child's legal position in family proceedings was repeatedly debated in society and in parliament in

11. Art. 1:233 Dutch Civil Code ('Burgerlijk Wetboek').

12. See M.M. Limbeek and M.R. Bruning, 'The Netherlands. Two Decades of the CRC in Dutch Case Law', in T. Liefaard and J.E. Doek (eds.), Litigating the Rights of the Child. The UN Convention on the Rights of the Child in Domestic and International Jurisprudence (2015) 89, at 92-93.

13. Children under the age of twelve do not have the right to access all files; see Dutch Supreme Court 5 December 2014, ECLI:NL:HR: 2014:3535 and for a critical reflection: T. Liefaard and M.R. Bruning, 'Commentary on the Judgement of the Hoge Raad on the 5th of December 2014', in H. Stalford, K. Hollingsworth and S. Gilmore (eds.), Rewriting Children's Rights Judgments. From Academic Vision to New Practice (2017) 173

14. Art. 1:245(4) Dutch Civil Code

15. Art. 1:250 Dutch Civil Code.

16. Arts. 1:251a(4) and 1:377g Dutch Civil Code.

17. Art. 798(2) Dutch Code of Civil Procedure.

18. Art. 809 Dutch Code of Civil Procedure; see also The Netherlands Supreme Court, 1 November 2013, ECLI:NL:HR:2013:1084 (annotated by S.F.M. Wortmann) the past few decades, the Dutch legislature has time and again made it clear that there is no reason to change the concept of legal incapacity of children in family proceedings. Nevertheless, in Dutch civil law, many exceptions to this principle can be distilled.

In Dutch family law, children from the age of sixteen and older are given some opportunities to initiate proceedings independently from their legal representatives in some particular situations. For example, an underage mother of sixteen years or older who wants to care for and raise her child under the right to exercise authority over it, may request the Juvenile Court to be emancipated. ${ }^{19}$ She also has legal capacity to act in court and to appeal against a court decision. A child who has reached the age of sixteen may request the District Court to be emancipated, in the sense that certain legal powers of an adult are granted to him by court order. ${ }^{20}$ In the court order decreeing the emancipation, the District Court explicitly specifies which legal powers of an adult are awarded to the child. The child may independently act as plaintiff or defendant in legal proceedings with regard to matters concerning the emancipation itself and with regard to juridical acts for which he has obtained full legal capacity pursuant to his emancipation. This is mostly used for family business matters in which children are participating and, therefore, need to have legal powers. In matters of adoption, a parent who has not yet reached the age of legal majority has full legal capacity to act in legal proceedings. ${ }^{21}$ Children from sixteen years of age and older can also initiate proceedings with regard to changing the registration of sex in their birth certificate. ${ }^{22}$ This law amendment of 2014 was inspired by Article 450 of Book 7 of the Dutch Civil Code, stating that, for medical treatment, children from the age of sixteen or older are legally competent to initiate proceedings. Medical treatment for children between twelve and sixteen years of age is only possible with 'double' informed consent of both parents (as legal representatives) and the child, but some exceptions exist to start medical treatment for this age group without parents' consent. ${ }^{23}$

For children who experience family supervision orders, exceptions to the legal incapacity of children are also incorporated in the Dutch Civil Law. Children who are twelve years of age or older can file requests to the court with regard to their complaints about the implementation of the family supervision order, such as a formal order from the child protection services that are responsible to supervise the child and the family. ${ }^{24}$ Children from the age of twelve or older can also request the court to terminate a family supervision order or an out-

19. Art. 1:253ha Dutch Civil Code

20. Art. 1:235 Dutch Civil Code.

21. Art. 1:227 sub 6 Dutch Civil Code.

22. This option was introduced for transgender people: Art. 1:28 lid 4 Dutch Civil Code (introduced by law amendment in 2014)

23. Art. 7:450 section 2 Dutch Civil Code. The exception conditions are 'serious risk for the child' and 'without parental consent, the child still has a strong wish for medical treatment and can oversee the consequences of this decision'.

24. Arts. 1:264 and 265 Dutch Civil Code. 
of-home placement of the child (in alternative care) that can be ordered in light of a family supervision order. ${ }^{25}$ Still, these children cannot appeal a family supervision order without their legal representative since they have no locus standi.

Another exception to the rule that children are legally incapacitated in civil proceedings was introduced in 2008, for children who experience secure treatment (out-of-home) placement. Because a secure treatment placement involves a serious human rights interference - a deprivation of the child's liberty - extra safeguards were introduced in legislation, and the child who risks or faces secure treatment placement is deemed legally competent to independently start legal proceedings or appeal a decision. ${ }^{26}$ In secure treatment placement proceedings, children are an independent party to the proceedings, have locus standi and are represented by a lawyer. ${ }^{27}$

Besides direct autonomous access to court proceedings, the Dutch Civil Code offers children who are twelve years or older the possibility to informally contact the court in the context of divorce proceedings and request that joint parental authority be converted to sole parental authority or to bring a case with respect to access rights or care plans subsequent to divorce. ${ }^{28}$ Children from the age of twelve and older can informally contact the court (e.g. by writing a letter or sending an email) without (legal) representation. Children younger than the age of twelve who are considered as competent can also use this opportunity. ${ }^{29}$ The court has discretionary power to decide about the child's request. No mandatory duty to hear the child in court or to give a formal legal decision exists. The child is not competent to autonomously appeal any decision in this context but can only appeal through his or her legal representative(s) or guardian ad litem $^{30}$ In practice, children's use of this 'informal access' to court remains trivial. ${ }^{31}$

Children can also request the court to appoint a guardian ad litem when there is a conflict of interests between the child and his or her parents or guardian as legal representatives in any matter about the upbringing and education of the child. ${ }^{32}$ The court can appoint a guard-

25. Art. 1: 265d Dutch Civil Code.

26. Art. 6.1.1(2) Dutch Youth Act ('Jeugdwet'); children from twelve years and older are independent parties to the proceedings with legal capacity, and children younger than twelve years have the same legal position when they are deemed competent.

27. Art. 6.1.1 section 2 Dutch Youth Act.

28. Arts. 1:251a section 4, 1:377g \& 1:253a section 4 Dutch Civil Code

29. This expansion for children younger than twelve years of age was introduced in 1995 by law amendment (see Wet van 6 April 1995 tot nadere regeling van het gezag over en van de omgang met minderjarige kinderen (1995)).

30. Dutch Supreme Court 29 May 2015, ECLI:NL:HR:2015:1409.

31. M.H.L. Van den Hoogen and P.J. Montanus, 'Hoe staat het anno 2017 met de informele rechtsingang?', 11 FJR 286 (2017).

32. See e.g. I.J. Pieters, 'De bijzondere curator: Quo vadis?', 9 FJR 180 (2008); I.J. Pieters, 'Waar staat de bijzondere curator in het huidige rechtsbestel inmiddels?', 4 FJR 97 (2012); I.J. Pieters, 'De groeistuipen van de bijzondere curator', 6 FJR 177 (2017); G.W. Brands-Bottema, 'De bijzondere curator: nieuwe ontwikkelingen', 10 EB Tijdschrift voor ian ad litem ex officio. The child can also request the appointment of a guardian ad litem. When the judge rejects the request to appoint a guardian ad litem, the child can appeal with the support of a legal representative. ${ }^{33} \mathrm{~A}$ significant increase in the number of appointed guardian ad litems has been visible in the last decade. Furthermore, a development of further professionalisation occurred and judges have become more acquainted with the possibility to appoint a guardian ad litem for children. ${ }^{34}$ Nevertheless, judges do not always appoint a guardian ad litem on request. When, for example, the child's interests are represented by his or her parents, child protection services or a social worker who is responsible for a child protection order, judges are reluctant to appoint a guardian ad litem $^{35}$ In legal parentage proceedings with children involved, judges will always have to appoint a guardian ad litem (ex officio) to represent the child. ${ }^{36}$ The court has no discretionary power in such proceedings.

As was mentioned, children from the age of twelve years or older must be given the opportunity to be heard in civil court proceedings and are invited for a court hearing. ${ }^{37}$ Only in child alimony proceedings, the age limit to invite children to be heard in court is sixteen years of age. ${ }^{38}$ The court has discretionary power to hear children younger than twelve years of age on their request when they are deemed competent. This group of children do not have the right to be heard since their being heard is left to the discretionary power of the court. Thus, children under the age of twelve are not automatically invited to participate in the court procedure and need to take action if they want to be heard in court. In practice, children under the age of twelve are rarely heard in family law proceedings. ${ }^{39}$

Scheidingsrecht 183 (2018); C.A.R.M. van Leuven and I.J. Pieters, 'Stichting bijzondere curator Nederland', 3 Relatierecht en Praktijk 39 (2018).

33. Dutch Supreme Court 3 February 2017, ECLI:NL:HR:2017:158.

34. A Guardian ad litem Foundation has been established, see van Leuven and Pieters, above n. 32. Moreover, professional standards have been developed (see Landelijk Overleg Vakinhoud Familie - en Jeugdrecht (LOVF), Werkproces benoeming bijzondere curator op grond van art. 1:250 BW,www.rechtspraak.nl; Leidraad werkwijze en verslag bijzondere curatoren ex art. 1:250 BW and Richtlijn Benoeming Bijzondere Curator o.g.v. art. 1:212 BW).

35. M.R. Bruning, et al., Kind in proces: van communicatie naar effectieve participatie (WODC-onderzoek) Nijmegen: Wolf Legal Publishers (2020), at 47-50; M.M.C. Limbeek, 'De bijzondere curator: een volwaardig sluitstuk van rechtsbescherming?', in J.H. de Graaf, C. Mak, P.J. Montanus \& F.K. van Wijk (eds.), Rechten van het Kind en Waardigheid (2013) 199; M.R. Bruning, 'Versterking van de procedurele positie van de minderjarige in het jeugdbeschermingsrecht - een brug te ver?', in W.H. van Boom et al. (eds.), Een kwart eeuw Privaatrechtelijke opstellen, aangeboden aan prof. mr. H.J. Snijders ter gelegenheid van zijn emeritaat (2016) 75.

36. Art. 1:212 Dutch Civil Code. See also the relevant court guidelines (Richtlijn benoeming bijzondere curator o.g.v. artikel 1:212 $B W$, www.rechtspraak.nl).

37. Art. 1:809 section 1 Dutch Code of Civil Procedure.

38. Art. 1:809 lid 1 Dutch Code of Civil Procedure.

39. Bruning et al., above n. 35, at 226; K.A.M. van der Zon and M.P. De Jong-de Kruijf, 'Hoger beroep tegen een uithuisplaatsingsbeslissing en de rol van de minderjarige', TREMA Tijdschrift voor de rechterlijke macht (2015), at 307; H.C.M. Aalders, 'De rechtspraktijk inzake 
For children twelve years or older, in the Dutch Code of Civil Procedure judges are given the opportunity to not hear these children only when it concerns a case of minimal relevance to the child. The Dutch legislator has underlined that when it is plausible that the child does not want to be heard, the judge is not obliged to hear the child. ${ }^{40}$ The same applies for children who are unable to be heard due to a physical or mental health problem. ${ }^{41} \mathrm{~A}$ last exception to the rule to hear every child of twelve years of age and older concerns the situation in which the judge fears that hearing the child will negatively influence the child's health and development. ${ }^{42}$

Courts and judges are not given any conditions or blueprint in legislation on how to hear the child in court. The Dutch Code of Civil Procedure remains silent about the way children should be heard in civil law proceedings. In 2015, the Courts of Appeal developed a professional standard of how the child should be heard. ${ }^{43}$

\subsection{Age Limits in Other Dutch Legal Contexts}

In other Dutch legal contexts, children's procedural rights are different. In criminal law, child suspects from the age of sixteen or older are given the same rights as adult suspects; in other words, they are seen as an independent party to the criminal proceedings. They can, for example, question witnesses. ${ }^{44}$ Children are represented by a lawyer in criminal proceedings, and the lawyer can also independently execute the child's rights when the child is younger than sixteen years of age, ${ }^{45}$ such as to initiate appeal proceedings.

In administrative law, no age limits are used with regard to the position of children. Children can independently start proceedings when they are considered competent to oversee the consequences of their decisions. ${ }^{46}$ The court will assess the child's competency in light of the individual circumstances of the case. The Youth Act 2015, a specific administrative legal act for all forms of support and care for children and families, encompasses a similar approach, and all children who are considered competent can initiate court proceedings, for example, to contest a decision of an administrative body in response to a request for youth care and support. These children can also independently appeal court decisions. The only exception to this individualised approach to children's procedural rights in administrative law, as mentioned, involves decisions in light of secure treat-

gezagsbeëindiging vanuit kinderrechtelijk perspectief', 11 FJR (2018/63), at 66.

40. Dutch Parliamentary Documents II 1992-93, 22487, 6, at 16; see also Dutch Supreme Court, 1 November 2013, ECLI:NL:HR:2013:1084.

41. Dutch Parliamentary Documents // 1991-92, 22487, 3, at 10.

42. Dutch Supreme Court, 1 November 2013, ECLI:NL:HR:2013:1084 (annotated by S.F.M. Wortmann).

43. See Professionele standaard kindgesprekken 9 December 2016, www.rechtspraak.nl. In practice, a child hearing in chambers lasts between 7, 5 and 19 minutes in Court of Appeal proceedings about out-of-home placement of children; Van der Zon and De Jong-de Kruijf, above n. 39.

44. Art. 292 section 3 Dutch Code of Criminal Procedure.

45. Art. 503 section 1 Dutch Code of Criminal Procedure.

46. Art. 8:21 section 2 Dutch General Administrative Law Act. ment placements of children that are covered by the Youth Act 2015. Since this particular situation of secure treatment placement is closely connected to other outof-home placements of children in alternative care as part of child protection, regulated in the Dutch Civil Code,${ }^{47}$ the age limit of twelve years of age that is adopted in civil law is used.

It has, thus, become clear that in different law regimes the procedural position of children varies and both age limits and an individualised competency test are used. It seems like different Dutch legal contexts envisage diverse child images with differing consideration of the child's evolving capacities and competency. ${ }^{48}$

\subsection{Political (Un)willingness to Improve the Child's Legal Position}

It can be concluded that the legal position of children in Dutch civil law is rather complex and fragmented and also differs from the child's position in other Dutch legal contexts. Over the past few decades several exceptions to the child legal incapability have been introduced in legislation, with various aims and motivations, ${ }^{49}$ but this has only led to a more complicated system with regard to the legal position of children, a system that includes so many exceptions to the rule of legal incapacity. In the Dutch civil law system, children are no independent parties and cannot instigate proceedings and appeal against decisions.

In recent history, several voices have been raised to encourage the Dutch legislature to improve children's position in civil proceedings, often based on research findings. ${ }^{50}$ According to the Dutch legislature, the child's best interests will be sufficiently represented by his parents or other legal guardians in most situations. When the child's interests conflict with the interests of his legal representative (parent or legal guardian) and this causes a serious conflict of interests, for example, with regard to the education and upbringing of the child, access to court is guaranteed via the appointment of a guardian ad litem; this legal possibility is considered sufficient by the legislator. ${ }^{51}$ In 1991, with regard to legal reform of family procedures, the legislator confirmed that children do not and should not have the legal capacity to initiate family proceedings. Children are not legal parties to proceedings and need to be represented by their parents or other legal guardians or by a guardian ad litem. ${ }^{52}$ In order to strengthen the legal

47. Art. 1:262b Dutch Civil Code.

48. Bruning et al., above n. 35 , at 68 .

49. Ibid., at 30-38.

50. See e.g. Dutch Parliamentary Documents I/ 1989-90, 21309, 2 (Notitie rechtspositie minderiarigen); Raad voor het Jeugdbeleid en Nederlandse Gezinsraad (1995); Dutch Parliamentary Documents // 1991-92, 21487, 3 at 7 (MvT); Dutch Parliamentary Documents II 2003-04, 29200 VI, 116, at 3; M.J. Steketee, A.M. Overgaag \& D. Lünneman, Minderiarigen als procespartij? Een onderzoek naar de bijzondere curator en formele rechtsingang voor minderiarigen (2003).

51. M.R. Bruning and T. Liefaard, 'The Netherlands Supreme Court (Hoge Raad)', in H. Stalford, K. Hollingsworth and S. Gilmore (eds.), Rewriting Children's Rights Judgements. From Academic Vision to New Practice (2017) 182, at 184

52. Ibid 
position of children in civil proceedings, the legislator clarified to have chosen to improve the child's possibilities to be represented by a guardian ad litem in cases where the child's best interests cannot be represented by a parent or other legal guardian, for example, in the situation of a conflict of interests. ${ }^{53}$ The legislator emphasised that the lack of an independent procedural position does not constitute a violation of Article 6 of the European Convention of Human Rights (guaranteeing access to an impartial tribunal) since the European Court on Human Rights has accepted the vulnerable position of children as a legitimised interference of this fundamental right. ${ }^{54}$

In 2003, in response to recommendations of a research project, commissioned by the Dutch Ministry of Justice, focused on the legal position of children in civil proceedings,${ }^{55}$ the legislator again took the same position in response to a research report focused on improvements of the legal position of children and the guardian ad litem. The legislator stated that the current possibilities of representation by a guardian ad litem when there is a conflict of interests between the child and his parents or other legal guardians were sufficient and it was unnecessary to introduce an independent legal position in civil proceedings for children. ${ }^{56}$ According to the legislator, the current system in which parents or other legal guardians represent their child, unless there is a conflict of interest, sufficed. That is, the child's legal position did not need to be strengthened and was sufficiently protected. ${ }^{57}$ The Ministry of Justice voiced a similar response to a research report of the Dutch Children's Ombudsman about the child's guardian ad litem in 2012. It was stated that the legal possibility to appoint a guardian ad litem is sufficient to guarantee the child's best interests, since the court has wide discretionary scope to appoint such a representative. A 'serious conflict of interests' needed for the court appointment of a guardian ad litem should, according to the legislator, not need to be interpreted strictly, like case law had shown, but could be widely interpreted. ${ }^{58}$ Not only when parents and their child obviously have direct conflicting interests, but also when parents are incapable of overseeing the issues concerning the child or of sufficiently representing these issues, one could speak of a 'serious conflict of interests' that requires the appointment of a guardian ad litem..$^{59}$ This means that the threshold for a court appointment of a guardian ad litem should be considered low. For instance, according to the legislator divorce or separation conflicts between two ex-partners could yet lead to the assumption of such a 'serious con-

53. Dutch Parliamentary Documents // 1991/92, 22487, 3, at 7.

54. Dutch Parliamentary Documents /I 1989/90, 21309, 2, at 21 (Notitie rechtspositie minderiarigen)

55. Steketee et al., above n. 50

56. Bruning and Liefaard, above n. 51, at 184.

57. Parliamentary Documents // 2003/04, 29200 VI, nr. 116, at 3.

58. Parliamentary Documents // 2012/13, 31 753, nr. 56.

59. Bruning and Liefaard, above n. 51, at 185. flict of interests' and, thus, lead to the appointment of a guardian ad litem for the child. ${ }^{60}$

The Dutch Government Committee on Reassessment of Parenthood reflected in its report of 2016 on the current statutory framework for hearing children and concluded that there are few objective arguments that can be proffered for a specific age limit of twelve years. ${ }^{61}$ The Government Committee was of the opinion that, on the one hand,

the hearing of children should preferably not be linked to a pre-determined age-limit, but instead should be determined on a case-by-case basis ... On the other hand, the Government Committee understands the need from a practical point of view to have clear age limits, from which a child should be heard. ${ }^{62}$

According to the Government Committee, children from the age of eight should have the right to be heard in procedures related to parentage and custody. Although the age limit of eight years is obviously equally arbitrary, the Committee believes that, in general, a child from this age can be presumed to be able to understand what decisions in the field of parentage and custody will mean, provided that they are explained to him or her. The Committee, therefore, recommended in 2016 that children from the age of eight should be granted the opportunity to be heard in procedures regarding parentage and custody and advised that the right of children to be heard should be placed in the context of a broader reflection of the position of children in Dutch procedural law. Furthermore, the Committee advised that the possibility of creating a formal procedure for children to bring a case to court should be examined. ${ }^{63}$ The Dutch government endorsed these recommendations in its coalition agreement of 2017, ${ }^{64}$ and in 2018, the Minister of Legal Protection announced that further research will be initiated. ${ }^{65}$

60. Ibid.

61. The Wiarda Commission argued in 1971 that the age limit of twelve corresponds to the moment that occurs in the life of every Dutch child when they move from primary to secondary school, and referenced to the criminal age of responsibility that is linked to twelve; see Commissie voor de herziening van het Kinderbeschermingsrecht, Jeugdbeschermingsrecht (1971), at 63.

62. Government Committee on Reassessment of Parenthood, above n. 4, at 27 and 28.

63. Ibid., at 28. According to the Committee, a formal procedure for children to bring a case would have the important advantage of providing the child with a formal position within the proceedings. The child would no longer be dependent upon the willingness of the court to honour an informal request of the child. At the same time, the Committee acknowledges that a formal procedure for children to bring a case to court also widens the scope for parents to bring cases to court through their child instead of in their own name, an undesirable situation.

64. Coalition Agreement 2017-2021, Vertrouwen in de toekomst (2017), at 6.

65. Letter of Dutch Minister of Legal Protection of 22 March 2018 ('Nadere invulling onderzoeken op het terrein van het familierecht'). This article is based on some of the findings of this research released in 2020, Bruning et al., above n. 35 
In this part of our review it has been made clear that in Dutch family law a tortuous jungle of age limits, exceptions and limitations regarding children's procedural rights has developed in the past few decades. In other Dutch legal contexts, different choices have been made and children's procedural position differs. Until recently, the Dutch government has been reluctant to improve the child's procedural position in family law, although in the last two years, the endorsement of the aforementioned recommendations of the Government Committee to further reflect on improvements to the child's procedural rights shows an opening and willingness that is an important step forward from a children's rights perspective.

In the next part, relevant neuropsychological insights will be presented. Moreover, it will be discussed what lessons can be learnt from these insights when reflecting upon age limits and the child's right to be heard and to initiate proceedings.

\section{Neuropsychological Insights}

\subsection{Neuropsychological Insights and the Child's Right to Be Heard}

In the first part of this review, it is mentioned that, according to Article $12 \mathrm{CRC}$, children have the right to be heard, and this includes the right for all children who are capable of forming their own views to express those views freely in any judicial proceedings, such as civil proceedings. The right to be heard as enshrined in Article 12 CRC includes three components: the right to information about being heard (1), the right to be heard (2) and the right to be taken seriously by way of their views being given due weight in accordance with the age and maturity of the child.

In order to effectively implement these components of Article 12 CRC, neuropsychological insights with regard to the child's development are crucial. In particular, developmental insights regarding the child's capability and maturity and resistance to possible influence or manipulation of the child's opinion. Furthermore, it is vital to have insight into the relevance for the child to be taken seriously by way of giving due weight to his or her views.

If we want to understand what children are capable of at a certain age, it is important to gain more insight into milestones and biological transition phases that affect cognitive and emotional processes. Such an important transition phase is adolescence - roughly spanning from age ten to age twenty-three - which entails the process of growing up from a child into becoming an adult member of society. Adolescence starts with the onset of puberty, a hormonal process that is related to brain development and emotional processing ${ }^{66}$ and already

66. J.S. Peper and R.E. Dahl, 'Surging Hormones: Brain-Behavior Interactions During Puberty', 22 Current Directions in Psychological Science 134 (2013). starts - on average - at age eight in girls and nine in boys ${ }^{67}$ As hormonal changes during puberty affect brain regions involved in affective processing (including emotion regulation, stress responsiveness and decision making under risk and uncertainty), it is important to recognise that these developmental effects are initiated way before the age of twelve.

Scientific studies into large-scale normative brain development are accumulating, using state-of-the-art neuroimaging techniques. ${ }^{68}$ Especially, longitudinal studies are informative when it comes to disentangling developmental effects from individual variation in brain and behavioural change. ${ }^{69}$

Developmental neuropsychology offers starting points for determining and reconsidering the legal position of children. For example, a recent publication by Grootens-Wiegers, Hein and colleagues examined neuroscientific mechanisms that may be relevant to the capacities of children in making medical decisions. ${ }^{70}$ Neuroscientific insights also have been applied in adolescent criminal law: the age limit in adolescent criminal law can be extended to twenty-three years, taking into account individual characteristics, based on the now widely replicated finding that brain development has not yet been completed with eighteen years, but extends on average to around twenty-three years. ${ }^{71}$ Although there have been reflections on the age limits on the right to be heard and the legal capacity to initiate family proceedings ${ }^{72}$ current insights from developmental neuropsychology have not yet been included in determining the procedural position of children within family law. As opposed to adolescent criminal law, this article is intended to reflect on the lomer age limit of the right to be heard and legal capacities to initiate family proceedings. Developmental brain imaging studies are usually carried out from eight years onward (up to twenty-five

67. M.E.A. Barendse, J.G. Simmons, M.L. Byrne, M.L. Steal, G. Patton, L. Mundy, S.J. Wood, C.A. Olsson \& S. Whittle, 'Brain Structural Connectivity During Adrenarche: Associations Between Hormone Levels and White Matter Microstructure', 88 Psychoneuroendocrinology 70 (2018).

68. E.A. Crone and R.E. Dahl, 'Understanding Adolescence as a Period of Social-Affective Engagement and Goal Flexibility', 13 Nature Reviews Neuroscience 636 (2012); B.J. Casey, A. Galvan \& L.H. Somerville, 'Beyond Simple Models of Adolescence to an Integrated Circuit-Based Account: A Commentary', 17 Developmental Cognitive Neuroscience 128 (2016); A.R. Smith, J. Chein \& L. Steinberg, 'Impact of Socio-Emotional Context, Brain Development, and Pubertal Maturation on Adolescent Risk-Taking', 64 Hormones and Behavior 323 (2013); C.K. Tamnes, M.M. Hertig, A.L. Goddings, R. Meuwese, S.J. Blakemore, R.E. Dahl, B. Güroğlu, A. Raznahan, E.R. Sowell, E.A. Crone \& K.L. Mills, 'Development of the Cerebral Cortex Across Adolescence: A Multisample Study of Inter-Related Longitudinal Changes in Cortical Volume, Surface Area, and Thickness', 37 Journal of Neuroscience 3402 (2017).

69. Mills et al., above n. 1.

70. P. Grootens-Wiegers, I.M. Hein, J.M. van den Broek \& M.C. de Vries, 'Medical Decision-Making in Children and Adolescents: Developmental and Neuroscientific Aspects', 17 BMC Pediatrics 120 (2017).

71. Tamnes et al., above n. 68; Mills et al., above n. 1; C. Lebel, L. Walker, A. Leemans, L. Phillips \& C. Beaulieu, 'Microstructural Maturation of the Human Brain from Childhood to Adulthood', 40 Neuroimage 1044 (2008).

72. C.C.M. van Leeuwen, 'Het hoorrecht in het civiele jeugdrecht gaat over grenzen', 10 FJR 260 (2017); Rap et al., above n. 6. 
years of age), spanning late childhood and adolescence. Therefore, in this part, an overview is first provided on the general patterns of brain development across late childhood and (early) adolescence, to obtain a broad sense of anatomical and functional brain changes occurring in this phase of development. This knowledge is relevant in guiding the interpretation of behaviour, cognitions and emotions based on the (neuro)psychological development. In other words, What can be expected from children within a certain developmental period? This is followed by a section on the development of language, perspective taking and executive functions. These are neurocognitive capacities that are relevant for (family) law, such as the capability to form and express an own view (which is not purely dependent on cognitive systems, though, but is also influenced by emotions and theory of mind skills). Finally, development of the psychological constructs autonomy, stress responsiveness and (peer) pressure are discussed in relation to the civil law context.

\subsection{Brain Development from Late Childhood into (Early) Adolescence}

With the development of sophisticated neuroimaging techniques over the last twenty years, it has become possible to study changes in the living brain. We will first briefly summarise current research on structural and functional brain changes taking place during the transition from childhood into adolescence.

This summary relies on the most recent evidence available and is not intended to be an exhaustive review of the literature; moreover, studies tend to use 'typically' developing adolescents, which limits our ability to comment on whether or how these processes may change for young people with developmental delays or across a broader spectrum of neurodiversity.

With structural magnetic resonance imaging (MRI), it has been found that changes occur in the brain's grey and white matter across childhood and adolescence. Grey matter includes the cerebral and subcortical brain structures and is, among others, composed of neuronal bodies, synapses (i.e. the site of transmission of electric nerve impulses between two nerve cells), glial cells (i.e. the cells that surround neurons and provide support for and insulation between them), dendrites and blood vessels. White matter largely comprises big, organised myelinated axons that connect grey matter brain regions. ${ }^{73}$

It has been shown that at six years of age, total brain volume already reaches $95 \%$ of its adult size. ${ }^{74}$ Then, total brain volume peaks around ten years of age, followed by a gradual decrease. ${ }^{75}$ This developmental pattern of total brain volume is strikingly similar between

73. P.R. Huttenlocher, 'Morphometric Study of Human Cerebral Cortex Development', 28 Neuropsychologia 6 (1990).

74. J.N. Giedd, A. Raznahan, A. Alexander-Bloch, E. Schmitt, N. Gogtay \& J.L. Rapoport, 'Child Psychiatry Branch of the National Institute of Mental Health Longitudinal Structural Magnetic Resonance Imaging Study of Human Brain Development', 40 Neuropsychopharmacology 1 (2015).

75. Mills et al., above n. 1. boys and girls ${ }^{76}$ and invalidates claims that brain development in boys is delayed as opposed to that in girls.

Researchers found that grey matter volume was highest in childhood, decreased across early and middle adolescence and began to stabilise in the early twenties; this pattern held even after accounting for intracranial and whole brain volume. Additional studies of cortical volume have also documented the highest levels occurring in childhood, with decreases from late childhood throughout adolescence - the decrease appearing to be due to the thinning of the cortex. ${ }^{77}$ For white matter volume, on the other hand, researchers found that, across samples, increases in white matter volume occurred from childhood through mid-adolescence and showed some stabilising in late adolescence. Some neural circuitry, consisting of networks of synaptic connections, is extremely malleable during adolescence, as connections form and reform in response to a variety of novel experiences and stressors. ${ }^{78}$

Next to these 'global' changes in gross morphology, regional developmental changes in brain areas and their interconnections have been reported as well. ${ }^{79}$ Theoretical models have emerged to explain how regional neurobiological changes map onto cognitive and emotional development from childhood into adolescence. Two of the often used models are the 'dual systems' model and the 'imbalance' model. The dual systems model ${ }^{80}$ describes the product of a developmental asynchrony between a quickly aroused reward system (the ventral striatum), which inclines adolescents toward sensation seeking, and still maturing self-regulatory regions (i.e. the prefrontal cortex (PFC)), which limit the young person's ability to resist these inclinations. ${ }^{81}$

The 'reward system' references subcortical structures, while the 'self-regulatory regions' refer to areas like the PFC.

The imbalance model shifts the focus away from an orthogonal, dual systems account and instead emphasises patterns of change in neural circuitry across adoles-

76. L.M. Wierenga, M. Langen, B. Oranje \& S. Durston, 'Unique Developmental Trajectories of Cortical Thickness and Surface Area', 15 Neuroimage 87 (2014).

77. Tamnes et al., above n. 68

78. F.Y. Ismail, A. Fatemi \& M.V. Johnston, 'Cerebral Plasticity: Windows of Opportunity in the Developing Brain', 21 European Journal of Paediatric Neurology 1 (2017); L.D. Selemon, 'A Role for Synaptic Plasticity in the Adolescent Development of Executive Function', 5 Translational Psychiatry 3 (2013).

79. Tamnes et al., above n. 68; A.C.K. van Duijvenvoorde, B. Westhoff, F. de Vos, L.M. Wierenga \& E.A. Crone, 'A Three-Wave Longitudinal Study of Subcortical-Cortical Resting-State Connectivity in Adolescence: Testing Age- and Puberty-Related Changes', 40 Human Brain Mapping 13 (2019)

80. E.P. Shulman, A.R. Smith, K. Silva, G. Icenogle, N. Duell, J. Chein \& L. Steinberg, 'The Dual Systems Model: Review, Reappraisal, and Reaffirmation', 17 Developmental Cognitive Neuroscience (2016); L. Steinberg, 'A Social Neuroscience Perspective on Adolescent Risk-Taking', 28 Developmental Reviews 1 (2008).

81. L. Sherman, L. Steinberg \& J. Chein, ‘Connecting Brain Responsivity and Real-World Risk Taking: Strengths and Limitations of Current Methodological Approaches', 33; 27-41 Developmental Cognitive Neuroscience (2018). 
cence. This fine-tuning of circuits is hypothesised to occur in a cascading fashion, beginning within subcortical regions (such as those within the limbic system), then strengthening across regions and, finally, occurring within outer areas of the brain like the PFC. ${ }^{82}$ This model corresponds with observed behavioural and emotional regulation - over time, most adolescents become more goal oriented and purposeful, and less impulsive. ${ }^{83}$ Irrespective of the differences between the two models of brain development and the relation to behaviour, they both converge on the point that fundamental areas of the brain undergo asynchronous development from childhood into adolescence. That is, adolescent behaviour, especially concerning increased risk taking and still-developing self-control, has been particularly attributed to asynchronous development within and between the subcortical and cortical regions of the brain. The former drives emotion, and the latter acts as the control centre for long-term planning, consideration of outcomes and regulation of behaviour. ${ }^{84}$ Thus, if connections within the limbic system develop faster than those within and between the PFC region, the imbalance may favour a tendency towards heightened sensitivity to peer influence, impulsivity, risk-taking behaviours and emotional instability. ${ }^{85}$

\subsection{Neurocognitive Capacities}

To obtain realistic predictions about the cognitive capacities needed to weigh different arguments, form an opinion, make a decision and oversee the consequences of that decision, it is important to get insights into the general developmental patterns of the underlying neurocognitive systems. All of these steps are directly relevant when reflecting on age boundaries within civil (family) law. Here, the development of cognitive capacities needed to form and express an (own) view will be highlighted, as well as the cognitive capacities needed to initiate proceedings.

On the level of language development (i.e. understanding of sentences and subsequent speech production), it has been demonstrated that the development of understanding and producing complex (i.e. multi-clause) sentences usually begins some time before the child's second birthday and is largely complete by age four. In general, comprehension precedes production. ${ }^{86}$ Verbalising an opinion, however, including labelling emotions or feelings, is much more difficult and continues to

82. Casey et al., above n. 68.

83. Ibid.

84. A. Galván, T.A. Hare, C.E. Parra, J. Penn, H. Voss, G. Glover \& B.J. Casey, 'Earlier Development of the Accumbens Relative to Orbitofrontal Cortex Might Underlie Risk-Taking Behavior in Adolescents', 26 Journal of Neuroscience 25 (2006); E.A. Crone and N. Steinbeis, 'Neural Perspectives on Cognitive Control Development during Childhood and Adolescence', 21 Trends in Cognitive Science 205 (2017).

85. B.J. Casey and K. Caudle, 'The Teenage Brain: Self Control', 22 Current Directions in Psychological Science 2 (2013); Giedd et al., above n. 74; Mills et al., above n. 1.

86. G. Farkas and K. Beron, 'The Detailed Age Trajectory of Roral Vocabulary Knowledge: Differences by Class and Race', 33; 464-497 Social Science Research (2004). develop until age ten to twelve. ${ }^{87}$ These ages are averages and, again, large individual differences exist as some children are able to verbalise an opinion at the age of four, whereas others still might have difficulties at the age of twelve. In addition to verbalising an opinion, this opinion first needs to be formed. This is a complex process of understanding information, integrating different perspectives and arguments and organising thoughts and feelings. Although children at the age of four can express their view based on arguments, they conform under the influence of peer pressure. ${ }^{88}$

Forming an opinion is also based on taking different perspectives, that is, reasoning about others and understanding what they think, feel or believe. ${ }^{89}$ Studies have shown that these 'theory of mind' skills develop in infancy by the age of five years. ${ }^{90}$ In an extensive metaanalysis of more than 170 independent studies it became clear that the basic understanding of other peoples' intentions and emotions is significantly developed at age six. ${ }^{91}$ However, these skills continue to fine-tune into the teenage years, ${ }^{92}$ paralleled by the maturation of the 'social brain network' (i.e. temporo-parietal junction, superior temporal gyrus and intraparietal lobe). ${ }^{93}$

Competence is one of the skills that is important when determining the legal position of children in civil law, certainly, when it concerns their own legal entry. Competence includes four domains - understanding, reasoning, valuing and making a choice - all part of executive functioning or higher order cognitive capacities. In clinical practice, extensive research has been carried out into will competence by Irma Hein. For her dissertation, she developed, among other things, a measuring instrument - the MacCat-T - to objectively measure the competence of children within medical scientific research. Hein's research showed that, with regard to participation in medical examinations, children under age 9.6 were generally not competent, whereas children above 11.2 were, with a transition area in between. ${ }^{94}$

Brain research also shows that executive functions, which are strongly related to the ability to make independent decisions and to oversee the consequences of actions, show a spectacular increase between ten and fif-

87. A. Diamond, 'Biological and Social Influences on Cognitive Control Processes Dependent on Prefrontal Cortex', 189; Progression in Brain Research 319 (2011).

88. D.B. Haun and M. Tomasello, 'Conformity to Peer Pressure in Preschool Children', 82 Child Development 6 (2011).

89. V. Gallese and A. Goldman, 'Mirror Neurons and the Simulation Theory of Mind-Reading', 2 Trends in Cognitive Science 12 (1998).

90. J. Barresi and C. Moore, 'Intentional Relations and Social Understanding', 19; 1667, Behavioral and Brain Sciences (1996).

91. H.M. Wellman, D. Cross \& J. Watson, 'Meta-Analysis of Theory-ofMind Development: The Truth About False Belief', 72 Child Development 3 (2001).

92. S. Choudhury, S.J. Blakemore \& T. Charman, 'Social Cognitive Development During Adolescence', 1 Social Cognitive Affective Neuroscience 3 (2006).

93. E.A. Crone and A.J. Fuligni, 'Self and Others in Adolescence', Annual Reviews of Psychology (2019; Epub ahead of print).

94. I. Hein, 'Children's Competence to Consent to Medical Treatment or Research' (PhD Thesis at VU, Amsterdam, 2015). 
teen years ${ }^{95}$ These findings are in line with those on the cognitive development of children, which showed a major leap again around the age of twelve, especially, in the field of abstract reasoning. ${ }^{96}$ This means, among other things, that children are increasingly able to think and reason about hypothetical situations, which is necessary when starting legal proceedings independently. For younger children, not only is abstract reasoning insufficiently developed, so that a child is unlikely to be able to see the hypothetical consequences of a legal procedure, the capacity to control impulses is also not yet optimally developed. However, these are relevant skills for initiating a (family) procedure.

Again, competence is usually determined based on cognitive skills. However, next to cognitive abilities, competence also entails emotional development, such as empathy (i.e. understanding others' emotions), or theory of mind. Interestingly, in the previous part, it was shown that most children at the age of six already have theory of mind skills.

Taken together, on the one hand, speaking capacity needed for verbalising an opinion, is - on average developed at age four. On the other hand, higher order cognitive functions needed for complex decision making and overseeing future consequences of these decisions (such as abstract reasoning, impulse control, executive functioning) are developing into the teenage years. These findings do not imply, however, that children should be without locus standi in civil law proceedings and be legally incompetent or too young to be heard in court under the age of twelve. First, there are substantial individual differences in cognitive abilities, and second, there is no such thing as 'pure' cognition - an opinion or decision is, regardless of age, affected by the level of emotional arousal, motivation and social context. ${ }^{97}$ Indeed, as the earlier mentioned imbalance model of brain development suggests, emotional and cognitive systems in the brain are highly connected and become more connected with age. ${ }^{98}$

Therefore, in the next section, it will be described how social-emotional functions develop and how these functions and the (social) context can influence cognition and decision making across late childhood and adolescent development. Aspects such as reward sensitivity, social rejection and stress will be discussed, as these are - similar to cognitive aspects - relevant for reflections on age limits for children's participation in family proceedings.

\subsection{Social-Emotional Functions and (Social) Context}

Social and emotional functions can be described as

95. L.M. Wierenga et al., 'Sex Effects on Development of Brain Structure and Executive Functions: Greater Variance than Mean Effects', 31 Journal of Cognitive Neuroscience 730-753 (2019) afl. 5

96. Diamond, above n. 87, at 319-339.

97. J. LeDoux, 'The Emotional Brain: From Soul to Synapses', 55 Biological Psychiatry S1 (2004).

98. Van Duijvenvoorde et al., above n. 79. the developing capacity of the child to form close and secure adult and peer relationships; experience, regulate, and express emotions in socially and culturally appropriate ways; and explore the environment and learn - all in the context of family, community, and culture. $^{99}$

It has been reported that children from four years onwards start to identify and articulate their own and other people's feelings. ${ }^{100}$ Importantly, when children's needs and feelings are consistently met by adults, they are better able to develop secure relationships, regulate their emotions and pay more attention to their surroundings. ${ }^{101}$

When it comes to meeting children's needs, this inherently means taking children seriously by - for example hearing them in family proceedings. According to Article 12 CRC, children's views should be given due weight in accordance with the age and maturity of the child. From earlier studies it became clear that children feel frustrated and powerless if they are not involved in important decisions about their lives. ${ }^{102}$ In addition, undermining the child's autonomy - by not being allowed to participate in family law proceedings or not being heard - leads to a decrease in self-esteem. ${ }^{103}$ Additionally, it is extremely important for children to be taken seriously: they indicate that they feel more respected when their opinion is noticed. ${ }^{104}$ In her dissertation 'Children, Autonomy and Courts', Daly argues:

Urging a movement towards respect for autonomy is likely to improve the situation of children. Autonomy is a useful and important concept because it is always about what one wants. It is also about insisting that we respect others - their lived experiences, their values, their beliefs; none of which a separate individual can ever truly understand. Autonomy should be much more about the obligations of adults to respect

99. T. Yates, M.M. Ostrosky, G.A. Cheatham, A. Fettig, L. Shaffer \& R.M. Santos, Research Synthesis on Screening and Assessing Social-Emotional Competence. Retrieved from Center on the Social Emotional Foundations for Early Learning (2008), http://csefel.vanderbilt.edu/ documents/rs_screening_assessment.pdf.

100. T.G. Halle and K.E. Darling-Churchill, 'Review of Measures of Social and Emotional Development', 45 Journal of Applied Developmental Psychology 8-18 (2016).

101. N. Eisenberg, T.L. Spinrad \& N.D. Eggum, 'Emotion-Related Self-Regulation and Its Relation to Children's Maladjustment', 6 Annual Review of Clinical Psychology 495-525 (2010).

102. V. Barnes, 'Social Work and Advocacy with Young People: Rights and Care in Practice', 42 British Journal of Social Work 7 (2012); C. Leeson, 'My Life in Care: Experiences of Non-participation in Decision-Making Processes', 12 Child \& Family Social Work 3 (2007); K. Winter, 'The Perspectives of Young Children in Care about Their Circumstances and Implications for Social Work Practice', 15 Child \& Family Social Work 2 (2010)

103. S.A. Vis, A. Strandbu, A. Holtan \& N. Thomas, 'Participation and Health - A Research Review of Child Participation in Planning and Decisionmaking', 16 Child \& Family Social Work 3 (2011).

104. G. Van Bijleveld, C.W.M. Dedding and J.F.G. Bunders-Aelen, 'Children's and Young People's Participation Within Child Welfare and Child Protection Services: A State-of-the-Art Review', 20 Child and Family Social Work 2 (2015). 
children and individuals, and to treat their choices as important, as it is about children's rights claims. ${ }^{105}$

From a neuroscience perspective, it can further be supported that experiences related to gaining respect can be very rewarding in young teenagers. ${ }^{106}$ For instance, primary rewards (such as money) in the teenage brain lead to a strong pattern of activity in the striatum - a brain region that processes rewarding stimuli. ${ }^{107}$ In addition to money, there are various other forms of rewards that affect the teenage brain, such as getting a compliment, ${ }^{108}$ but possibly also experiencing autonomy. ${ }^{109}$ Research in the United States has shown that certain interventions in high schools (aimed at a healthier lifestyle or aimed at reducing bullying) work particularly well with teenagers when their opinion is being heard and when their sense of autonomy is increased. ${ }^{110}$ For example, when teenagers are asked to come up with solutions for various problems at school (such as aggression, unhealthy eating, bullying behaviour).

On the other hand, it has been found that if adults (repeatedly) violate the sense of respect and autonomy of young adolescents by not taking them seriously or not hearing them, this can lead to decreased self-confidence and self-image and behavioural problems. ${ }^{111}$ In girls, these behavioural problems are more common in the form of internalising behaviour, such as depression or anxiety. In boys, behavioural problems are more often expressed in the form of externalising behaviour, such as aggression and problems with impulse control. ${ }^{112}$

In addition, children and adolescents who have been repeatedly rejected, for example by peers, experience

105. A. Daly, Children, Autonomy and the Courts. Series: Stockholm Studies in Child Law and Children's Rights (2017), at 435.

106. L.E. Sherman, A.A. Payton, L.M. Hernandez, P.M. Greenfield \& M. Dapretto, 'The Power of the Like in Adolescence: Effects of Peer Influence on Neural and Behavioral Responses to Social Media', 27 Psychological Science 1027 (2016).

107. E. Schreuders, B.R. Braams, N.E. Blankenstein, J.S. Peper, B. Guroglu \& E.A. Crone, 'Contributions of Reward Sensitivity to Ventral Striatum Activity Across Adolescence and Early Adulthood', 89 Child Development 797 (2018); B.R. Braams, A.C.K. van Duijvenvoorde, J.S. Peper \& E.A. Crone, 'Longitudinal Changes in Adolescent Risk-Taking: A Comprehensive Study of Neural Responses to Rewards, Pubertal Development, and Risk-Taking Behavior', 35 Journal of Neuroscience 7226 (2015).

108. M. Achterberg, A.C.K. Duijvenvoorde, M. van der Meulen, S. Euser M.J. Bakermans-Kranenburg \& E.A. Crone, 'The Neural and Behavioral Correlates of Social Evaluation in Childhood', 24 Developmental Cognitive Neuroscience 107 (2017).

109. J. Reeve and W. Lee, 'A Neuroscientific Perspective on Basic Psychological Needs', 87 Journal of Personality 102 (2019).

110. D.S. Yeager, R.E. Dahl \& C.S. Dweck, 'Why Interventions to Influence Adolescent Behavior Often Fail but Could Succeed', 13 Perspectives on Psychological Science 101 (2018).

111. J.P. Allen, S.T. Hauser, K.L. Bell \& T.G. O'Connor, 'Longitudinal Assessment of Autonomy and Relatedness in Adolescent-Family Interactions as Predictors of Adolescent Ego Development and Self-esteem', 65 Child Development 179 (1994).

112. R.D. Laird, K.Y. Jordan, K.A. Dodge, G.S. Pettit \& J.E. Bates, ‘Peer Rejection in Childhood, Involvement with Antisocial Peers in Early Adolescence, and the Development of Externalizing Behavior Problems', 13 Developmental Psychopathology 337 (2001). mental health problems that persist into adulthood. ${ }^{113} \mathrm{~A}$ possible mechanism that underlies the mental problems and rejection by peers is an increased emotional and neural reactivity in response to negative treatment, such as being ignored or being rejected. ${ }^{114}$ For example, it was reported that feelings of social rejection and exclusion lead to a pattern of brain activity in areas that are also involved in physical pain. ${ }^{115}$ Such effects can already be measured in children under the age of ten. ${ }^{116}$ Thus, scientific literature suggests that taking children seriously (e.g. by being heard or being allowed to give an opinion, and also receiving feedback about the judge's decision) is highly rewarding and essential for their well-being. In addition, brains of children react strongly to feelings of exclusion, like being left out of (or not being heard in) civil proceedings that directly affect the child. The negative effects of exclusion on mental wellbeing can already be demonstrated in children from ten years onwards and might continue into adulthood. The aforementioned findings are directly relevant to legal practice, in which currently (young) teenagers are often not heard or are unable to independently initiate legal proceedings. Although children often indicate that they want to be heard or give their opinion, this is not always granted because of the assumption that, for example, the child conversation is stressful and young children are insufficiently resilient. Individual differences in stress sensitivity and the development of the stress system in children will now be addressed, as well as the circumstances that may play a reinforcing or protective role.

Initiating legal proceedings or participating in a child conversation with a judge can be experienced as upsetting or can even be stressful or burdensome. ${ }^{117}$ This is partly due to unfamiliarity with the youth assistance system or legal practice, but also with the impact of the decision. ${ }^{118}$

Adrenaline and cortisol are the two hormones that control the physical response to stress. Adrenaline is released from the adrenal gland within seconds, while cortisol acts more slowly and regulates the initial stress

113. G.W. Ladd, 'Peer Rejection, Aggressive or Withdrawn Behavior, and Psychological Maladjustment from Ages 5 to 12: An Examination of Four Predictive Models', 77 Child Development 822 (2016); M.J. Prinstein and J.W. Aikins, 'Cognitive Moderators of the Longitudinal Association Between Peer Rejection and Adolescent Depressive Symptoms', 32 Journal of Abnormal Child Psychology 147 (2004).

114. G.J. Will, E.A. Crone, P.A. van Lier \& B. Guroglu, 'Neural Correlates of Retaliatory and Prosocial Reactions to Social Exclusion: Associations with Chronic Peer Rejection', 19 Developmental Cognitive Neuroscience 288 (2016).

115. Will et al., above n. 114; G.J. Will, P.A. van Lier, E.A. Crone \& B. Guroglu, 'Chronic Childhood Peer Rejection is Associated with Heightened Neural Responses to Social Exclusion During Adolescence', 44 Journal of Abnormal Child Psychology 43 (2016).

116. E. Peters, J.M. Riksen-Walraven, A.H. Cillessen \& C. de Weerth, 'Peer Rejection and HPA Activity in Middle Childhood: Friendship Makes a Difference', 82 Child Development 1906 (2011).

117. J. Cashmore and P. Parkinson, 'Children's Participation in Family Law Disputes: The Views of Children, Parents, Lawyers and Counsellors', 82 Family Matters 15 (2009).

118. R. Nathanson and K.J. Saywitz, 'Preparing Children for Court: Effects of a Model Court Education Program on Children's Anticipatory Anxiety', 33 Behavioral Science Law 459 (2015). 
response. ${ }^{119}$ In contrast to short-term exposure to stress, long-term exposure to stress actually leads to a weakened cortisol response, ${ }^{120}$ which may indicate reduced resilience. Although partly determined by genetic effects (i.e. individual differences in stress sensitivity or resilience related to genetic differences between people ${ }^{121}$ ), the environment also influences stress sensitivity. Exposure to early life adversity (such as mental and physical abuse) causes a weakened cortisol response that persists into adulthood. ${ }^{122}$ With regard to brain development, research has shown that (chronic) exposure to stress in early childhood has adverse effects on the development of various brain areas, including the amygdala and hippocampus. ${ }^{123}$ These areas remained poorer connected and were associated with poorer memory and more internalising behaviour. ${ }^{124}$

As mentioned earlier, children are sensitive to acceptance and rejection. For example, research has shown that peer evaluation and exclusion have a negative effect on the cortisol response. ${ }^{125}$ These effects have already been demonstrated in children under ten years of age. ${ }^{126}$ There are certain child characteristics and 'buffering/ protective' circumstances under which this pathological stress response can be partially restored or overcome. For example, children who have a higher level of selfcontrol and better cognitive reappraisal skills (i.e. being able to reinterpret and keep thoughts and behaviour under control) have a more resilient cortisol response. ${ }^{127}$ In light of legal proceedings, it can be suggested that if a child is allowed to participate in a family-related procedure, this increases the sense of self-control, which may possibly reduce the stress response.

Moreover, high-quality friendships during adolescence also provide higher resilience and better mental health later in life. ${ }^{128}$ In addition, it has recently been shown

119. J.C. Pruessner, K. Dedovic, M. Pruessner, C. Lord, C. Buss, L. Collins, A. Dagher \& S.J. Lupien, 'Stress Regulation in the Central Nervous System: Evidence from Structural and Functional Neuroimaging Studies in Human Populations - 2008 Curt Richter Award Winner', 35 Psychoneuroendocrinology 179 (2010).

120. Y.I. Kuras, N. Assaf, M.V. Thoma, D. Gianfarante, L. Hanlin, X. Chen, A. Fiksdal \& N. Rohleder, 'Blunted Diurnal Cortisol Activity in Healthy Adults with Childhood Adversity', 11 Frontiers in Human Neuroscience 574 (2017).

121. Pruessner et al., above n. 119

122. Kuras et al., above n. 120.

123. P. Pervanidou and G.P. Chrousos, 'Early-Life Stress: From Neuroendocrine Mechanisms to Stress-Related Disorders', 89 Hormone Research in Paediatrics 372 (2018).

124. J.L. Hanson, A.R. Knodt, B.D. Brigidi \& A.R. Hariri, 'Lower Structural Integrity of the Uncinate Fasciculus is Associated with a History of Child Maltreatment and Future Psychological Vulnerability to Stress', 27 Development and Psychopathology 4 Pt 2 (2015).

125. E. van den Bos, M. Tops \& P.M. Westenberg, 'Social Anxiety and the Cortisol Response to Social Evaluation in Children and Adolescents', 78 Psychoneuroendocrinology 159 (2017).

126. M.R. Gunnar, A.M. Sebanc, K. Tout, B. Donzella \& M.M. van Dulmen, 'Peer Rejection, Temperament, and Cortisol Activity in Preschoolers', 43 Developmental Psychobiology 346 (2003); Peters et al., above n. 116.

127. A.E. Johnson, N.B. Perry, C.E. Hostinar \& M.R. Gunnar, 'CognitiveAffective Strategies and Cortisol Stress Reactivity in Children and Adolescents: Normative Development and Effects of Early Life Stress', 69 Developmental Psychobiology 999 (2019).

128. A.L. van Harmelen, R.A. Kievit, K. Ioannidis, S. Neufeld, P.B. Jones, E. Bullmore, R. Dolan, NSPN Consortium, P. Fonagy \& I. Goodver, that thinking back to positive life experiences has a protective effect against the development of depression in teenagers with a history of early life stress. ${ }^{129}$ Research into the physical long-term effects of a divorce or an out-of-home placement in alternative care (i.e. foster care) has been carried out to a very limited extent. A warmer bond between mother and child after a divorce predicted a less strong cortisol response fifteen years after the divorce. ${ }^{130}$ Only the degree of warmth as reported by the child itself, and not as reported by the mother, was related to the long-term stress response. This finding is directly relevant for legal proceedings, because it argues for hearing the child itself (instead of one of the parents only) - as the child gave the most accurate description of the relationship with the mother. All in all, children are vulnerable when it comes to exposure to stressors (such as possibly having a child conversation or having their own legal entry). However, certain environmental factors and child traits can help children to better cope with stress, such as the feeling of being in control, maintaining close friendships with peers and being able to reinterpret and control thoughts and behaviour. In addition, children have mixed rather than exclusively positive or negative feelings about participation in a court case, ${ }^{131}$ whereby the negative aspects (i.e. stress and/or loyalty conflict) do not outweigh the importance of participating (i.e. being in control, being taken seriously and the wish to matter). ${ }^{132,133}$

\section{Children's Participation in Court: Room for Improvement?}

Article 12 CRC reflects the child's right to be provided the opportunity to be heard in any proceedings affecting the child. ${ }^{134}$ States parties to the CRC, such as the

'Adolescent Friendships Predict Later Resilient Functioning Across Psychosocial Domains in a Healthy Community Cohort', 47 Psychological Medicine 2017 (2017).

129. A.D. Askelund, S. Schweizer, I.M. Goodver \& A.L. van Harmelen, 'Positive Memory Specificity is Associated with Reduced Vulnerability to Depression', 3 Nature Human Behaviour 265 (2019).

130. L.J. Luecken, M.J. Hagan, S.A. Wolchik, I.N. Sandler \& J.Y. Tein, 'A Longitudinal Study of the Effects of Child-Reported Maternal Warmth on Cortisol Stress Response 15 Years After Parental Divorce', 78 Psychosomatic Medicine 163 (2016).

131. M. Bell, 'Promoting Children's Rights Through the Use of Relationship', 7 Child \& Family Social Work 1 (2002); J. Cashmore, 'Promoting the Participation of Children and Young People in Care', 26 Child Abuse \& Neglect 8 (2002).

132. Cashmore and Parkinson, above n. 117; Van Bijleveld et al., above n. 104.

133. Ibid. J.S. Peper and D.J.H. Smeets, 'Inzichten vanuit de pedagogische wetenschappen en de neuropsychologie', in M.R. Bruning et al., Kind in proces: van communicatie naar effectieve participatie, Meijers-reeks nr. 335 (2020).

134. In this article, we have not discussed how the child should preferably be heard - directly or through a representative or an appropriate body. Nevertheless, our research findings clearly indicate that directly hearing the child in court proceedings is preferable from the point of view of 
Netherlands, are given much leeway in how to implement this children's right and whether or not to use age limits as a means to define which children should be deemed capable of forming their own views. Still, the CRC Committee discourages states parties from introducing age limits in either law or practice that would restrict the child's right to be heard. The CRC Committee emphasises that children's capability to express their own views should be determined on a caseby-case basis and this requires an individual assessment of each individual child. When age limits are used, this should not be an absolute impediment and should not hinder younger children who are capable of forming their views from being heard. The CRC and the CRC Committee have not taken a stand on whether children should have locus standi in legal proceedings and be able to, independently of their legal guardians, initiate legal proceedings or file an appeal.

In the Netherlands, age limits in civil law proceedings are common ground, both regarding the right to be invited to be heard in court and the right to initiate proceedings. As mentioned earlier, children are deemed to be legally incompetent in civil law proceedings, but many exceptions to this rule were introduced in Dutch legislation in the past few decades - without a common approach to children's procedural rights in civil law and this has led to a complicated, fragmented civil law system. Nevertheless, in Dutch criminal law and administrative law, other perspectives are found regarding the child's procedural rights. In administrative law, the child's capability to express his or her own views is assessed on an individual basis, and in criminal law, child suspects have a stronger procedural position. It, therefore, seems that these legal contexts envisage diverse child images with differing considerations of the child's evolving capacities and competency. Several research reports about the child's procedural position in family law of the past few decades have instigated parliamentary discussions about improving the child's position, but, time and again, from the perspective of the Dutch legislator it was stressed that children should be represented by their parents or other legal guardians and when this is impossible due to a serious conflict of interests, the court can appoint a guardian ad litem for the child. In civil law, no law amendments were deemed necessary to give children locus standi or lower age limits, for example, the age limit of twelve years of age for being invited to be heard in court in family proceedings. In this article, we have presented relevant neuropsychological insights that can enrich reflections upon current age limits and possible improvements, not only for Dutch civil (family) law, but also for any country using age limits in legislation for children's procedural position. We have stated that adolescence starts with the onset of puberty, a hormonal process that is related to brain development and emotional processing, and already starts - on average - at age eight in girls and

both Dutch youngsters and Dutch family and children's judges; see Bruning et al., above n. 35, at 205-208. nine in boys. It is important to recognise that these developmental effects are initiated way before the age of twelve. To obtain realistic predictions about the cognitive (and social-emotional) capacities needed to weigh different arguments, form an opinion, make a decision and oversee the consequences of that decision, it is important to be aware of the general developmental patterns of the underlying neuronal systems of children. The development of understanding and producing complex sentences usually begins some time before the child's second birthday and is largely complete by age four. Studies have shown that 'theory of mind' skills develop in infancy by the age of five to six years but continue to fine-tune into the teenage years. These findings imply that the age limit of twelve years to invite children to be heard in court in family law proceedings is no longer tenable. However, it is important to note that there are substantial individual differences in cognitive abilities and that there is no such thing as 'pure' cognition: an opinion or decision is - regardless of age affected by the level of emotional arousal, motivation and social context.

Emotional processes and social context can influence cognitive functioning and decision making across adolescent development. From a neuropsychological perspective, the concepts of autonomy and well-being, resistance to pressure and stress are relevant for a further reflection on age limits. As mentioned earlier, research findings show that rewards are a strong motivational incentive for (young) teenagers; having a free choice or the feeling of being able to exert control over decisions makes the brain more resilient in negative settings and possibly also increases performance. On the other hand, if adults violate the sense of respect and autonomy of young adolescents by not taking them seriously, this can lead to decreased self-esteem and selfimage and behavioural problems. This implies that taking children seriously by being heard in court is highly rewarding and essential for their well-being. In addition, brains of children react strongly to feelings of exclusion, like not being heard in civil proceedings that directly affect the child. Most children indicate that they want to be heard by a judge, ${ }^{135}$ but nevertheless children under the age of twelve years are hardly ever heard in Dutch family law proceedings. This often seems to be based on the assumption that child hearings in court are stressful and that young children are insufficiently resilient.

Scientific research shows that children are indeed vulnerable when it comes to exposure to stressors, such as a child hearing in court. However, certain environmental factors and child traits can help children to better cope with stress, such as the feeling of being in control, maintaining close friendships with peers and being able to reinterpret and control thoughts and behaviour. In addition, children have mixed rather than exclusively positive or negative feelings about participation in court proceedings, whereby the negative aspects do not outweigh the importance of participating. It is, therefore, 
evident that even though participation in family law proceedings will lead to stress for children, this is no excuse to not let them participate in court, and protective factors are important for children to better cope with stress.

Overall, it should be noted that models of brain development do not - and cannot - specify at which age a child is fully capable of independent decision making or forming an authentic opinion. First, these complex cognitive processes are hard to measure using a task suitable for MRI. Second, there are many individual differences between children, and studies on brain development merely provide insights into average patterns of development across large samples. Third, besides biological factors like the brain, environmental factors, or social context, influence (cognitive) functioning. For instance, under emotionally arousing situations, adolescents may be more prone to be influenced by affective states, whereas under emotionally calm situations, they are more prone to make cognitively driven choices. ${ }^{136}$

In conclusion, what can we learn from these neuropsychological insights in light of age limits for children in civil law? There are no easy answers to this question. Neuropsychological insights reveal that an age limit of twelve years for children to be heard in court is not only arbitrary, but also unnecessarily restrains children's right to be heard in proceedings to an extent that is not legitimate. Children younger than twelve years of age are also competent and with a child-friendly system, including support factors, can be considered capable of forming their own views. Besides their capacities or competency to form and express their own views, taking children seriously in the courtroom is highly rewarding and essential for the child's well-being and can help avoid feelings of exclusion that lead to damage for the child.

With regard to the child's procedural position to initiate proceedings and file and appeal as an autonomous party to the proceedings, one could wonder if the neuropsychological insights that were presented in part 3 also lead to the conclusion that children should have locus standi and be given the right to autonomous party status. We are more reluctant to conclude likewise, since expressing one's voice when being heard in court and independently initiating family proceedings seem to differ with regard to the impact of decision for the child. We recommend further research from a multidisciplinary perspective.

When considering the right to be heard, we are confident that the current age limit in Dutch civil law should be lowered. From a neuropsychological perspective, the best option would be to individually assess each individual child and determine his or her competency on a case-by-case basis. Nevertheless, using age limits has the advantage of a clear system in which the judiciary does not have the burden to organise a system for indi- vidual assessments, but can focus on inviting all children from a certain age to be heard in court. As long as an age limit gives room to include children under the age limit who are competent and wish to be heard, age limits are permitted. We, therefore, recommend from a legal perspective that the Dutch age limit for hearing children in court in family proceedings should be lowered to at least eight years. With regard to other age limits in Dutch civil law that were mentioned earlier, a thorough review is necessary in order to decide about the child's possibilities to independently start proceedings or file a complaint in cases of separation, divorce and custody and in cases of child protection and out-ofhome placement. This includes a thorough reflection on possible forms of support or (legal) representation in court for children, who now hardly ever have any possibilities to be legally represented in family law proceedings.

We hope to have clarified that scientific collaboration between the disciplines of law and neuropsychology is fruitful and crucial when children who experience legal proceedings are concerned. The legislature can no longer deny scientific neuropsychological insights and will have to embrace collaboration with social sciences. Nevertheless, neuropsychological findings will not offer any clear blueprint for new legislation regarding children in legal proceedings nor give a clear answer to legal questions about how to define certain groups of children, since every child is different and needs to be approached as an individual with specific characteristics. It is not always possible to bridge the gap between various disciplines. Still, it is worthwhile getting to know each other and trying to build the contours of a bridge. There is still much to learn and much to be gained when reflecting upon children in court proceedings. Striving to effectively implement Article 12 CRC in order to better hear children themselves in court proceedings should involve further multidisciplinary scientific collaboration and integration of scientific findings across multiple domains. 